\title{
Characterization of Iberian species of the genus Pungentus Thorne \& Swanger, 1936 (Nematoda, Dorylaimida, Nordiidae)
}

\author{
Reyes PEÑA-SANTIAGO ${ }^{1,3, *}$, Marcel CIOBANU ${ }^{1,2,4}$ and Joaquin ABOLAFIA ${ }^{1,5}$ \\ ${ }^{1}$ Departamento de Biología Animal, Vegetal y Ecología, Universidad de Jaén, Campus "Las \\ Lagunillas" s/n, Edificio B3, 23071- Jaén, Spain \\ ${ }^{2}$ Institute of Biological Research, Department of Plant and Animal Taxonomy and Ecology, 48 \\ Republicii Str., RO-400015 Cluj-Napoca, Romania \\ *Corresponding author: rpena@ujaen.es \\ ${ }^{3}$ urn:Isid:zoobank.org:author:15EDFBB8-F905-4379-B247-2C2ADBC596AE \\ ${ }^{4}$ urn:lsid:zoobank.org:author:237A3F1F-AB01-4B92-979B-77718B6D0C1E \\ ${ }^{5}$ urn:1sid:zoobank.org:author:D7E30782-F6F2-48CA-B26F-9CA512FEC078
}

\begin{abstract}
Several populations of four known species of the genus Pungentus (P. clavatus, P. engadinensis, P. marietani and P. silvestris), collected in the wild and in cultivated soils from the Iberian Peninsula, are studied. Detailed redescriptions and morphometrics are presented for each species. Illustrations are provided, including line drawings, light microscopy pictures of the four species as well as scanning electron microscopy observations of $P$. engadinensis. The Iberian populations are compared to type and other known populations, and new data are given that provide a better characterization of these taxa. Pungentus engadinensis is the most widely distributed species in the Iberian Peninsula.
\end{abstract}

Keywords. Free-living nematodes, Iberian Peninsula, morphology, Pungentus, taxonomy.

Peña-Santiago R., Ciobanu M. \& Abolafia J. 2013. Characterization of Iberian species of the genus Pungentus Thorne \& Swanger,1936 (Nematoda, Dorylaimida, Nordiidae). European Journal of Taxonomy 52: 1-17. http:// dx.doi.org/10.5852/ejt.2013.52

\section{Introduction}

The genus Pungentus Thorne \& Swanger, 1936 is an interesting dorylaimid nematode genus. Its species are common inhabitants of natural forest areas of the Holarctic range. So far, five species of Pungentus have been recorded for the Iberian fauna (see compendium in Peña-Santiago et al. 2003). A sixth species, namely P. intertextus (Thorne \& Swanger, 1936) was recently transferred to Stenodorylaimus ÁlvarezOrtega \& Peña-Santiago, 2011. Nevertheless, no morphological or taxonomical study of these Iberian taxa was ever carried out and their identity was never confirmed. General nematological surveys, mainly conducted in the southern Iberian Peninsula during the last three decades to explore the dorylaimid fauna of this region, yielded many populations of Pungentus. 
Here, we present a detailed examination of this material, which allowed the characterization of four species and confirmation of their presence in the Iberian Peninsula.

\section{Material and Methods}

Nematodes were collected mainly in natural areas of the southern Iberian Peninsula during several nematological surveys conducted in the last three decades. They were extracted from soil samples using the methods by Baermann (1917) and Flegg (1967), relaxed and killed by heat, fixed in 4\% formaldehyde, processed to anhydrous glycerine following Siddiqi's (1964) technique, and mounted on permanent glass slides to allow handling and observation under light microscopy (LM). Morphometrics (Table 1) included de Man's indices and most of the usual measurements; the location of pharyngeal gland nuclei (DN, $\mathrm{S}_{1} \mathrm{~N}$ and $\mathrm{S}_{2} \mathrm{~N}$ ) is provided after the scheme proposed by Loof \& Coomans (1970). Some of the best preserved specimens were photographed with a Nikon Eclipse 80i microscope and a Nikon DS digital camera. Raw photographs were edited using Adobe ${ }^{\circledR}$ Photoshop ${ }^{\circledR}$ CS. Drawings were made using a camera lucida attached to the light microscope. After their examination and identification, a few specimens of Pungentus engadinensis, preserved in glycerine, were processed for observation under SEM following the protocol by Abolafia \& Peña-Santiago (2005). The nematodes were hydrated in distilled water, dehydrated in a graded ethanol and acetone series, critical point dried, coated with gold, and observed with a JEOL JSM-5800 microscope.

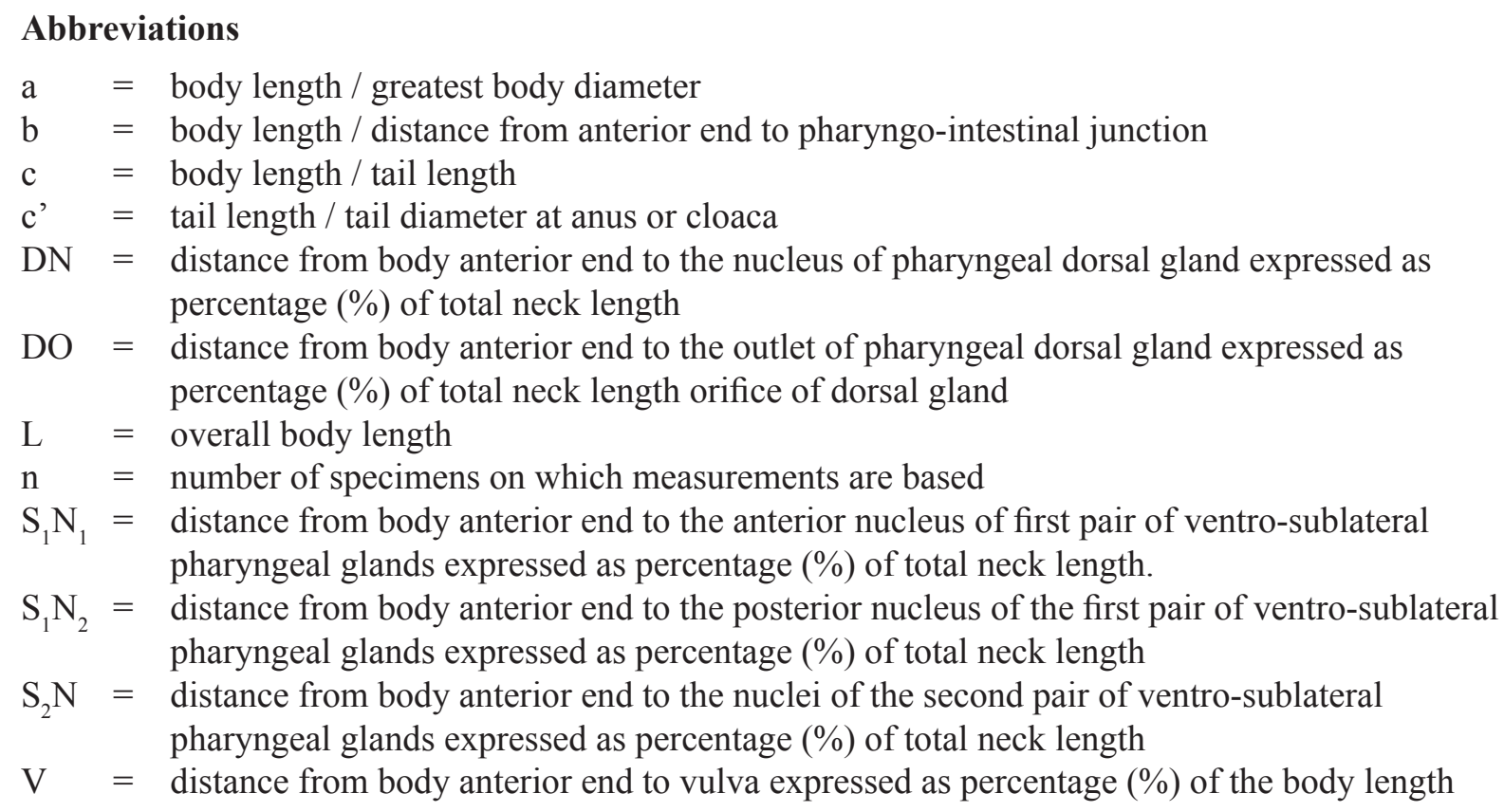


Table 1. Morphometrics of Iberian populations of the genus Pungentus Thorne \& Swanger, 1936. Measurements in $\mu \mathrm{m}$ (except $\mathrm{L}$, in $\mathrm{mm}$ ).

\begin{tabular}{|c|c|c|c|c|c|c|c|c|}
\hline \multirow{4}{*}{$\begin{array}{c}\text { Species } \\
\text { Habitat } \\
\text { Province } \\
\text { Character }\end{array}$} & & \multicolumn{2}{|c|}{ P. clavatus } & \multirow{3}{*}{\multicolumn{2}{|c|}{$\begin{array}{c}\text { P. engadinensis } \\
\text { Several } \\
\text { Several }\end{array}$}} & \multirow{4}{*}{$\begin{array}{c}\text { P. marietani } \\
\text { Brushwood } \\
\text { Granada } \\
5 \text { 우 }\end{array}$} & \multicolumn{2}{|c|}{ P. silvestris } \\
\hline & \multirow[b]{3}{*}{$\mathbf{n}$} & \multirow{3}{*}{$\begin{array}{c}\text { Pine forest } \\
\text { Granada } \\
7+\circ+ \\
\end{array}$} & \multirow{3}{*}{$\begin{array}{c}\text { Brushwood } \\
\text { Huesca } \\
2 q q \\
\end{array}$} & & & & Pine forest & Pine forest \\
\hline & & & & & & & Jaén & Granada \\
\hline & & & & 13 우우 & $\pi$ & & 10 우우 & 10 우우 \\
\hline $\mathbf{L}$ & & $1.37-1.83$ & $1.54,1.45$ & $0.77-1.21$ & 0.90 & $1.15-1.56$ & $1.47-1.90$ & $1.65-2.10$ \\
\hline a & & $35-42$ & $?$ & $33-39$ & 35 & $25-38$ & $34-40$ & $35-42$ \\
\hline b & & $3.5-4.4$ & $3.5,4.4$ & $3.4-4.4$ & 3.8 & $3.5-4.9$ & $3.5-4.6$ & $3.7-4.8$ \\
\hline c & & $52-70$ & 70,56 & $46-62$ & 56 & $53-71$ & $51-71$ & $55-70$ \\
\hline$c^{\prime}$ & & $0.7-1.0$ & $?$ & $0.8-1.0$ & 0.8 & $0.7-0.9$ & $0.7-0.9$ & $0.7-0.8$ \\
\hline $\mathbf{V}$ & & $41-45$ & 42,48 & $42-54$ & - & $44-49$ & $41-45$ & $42-47$ \\
\hline Lip region diameter & & $13-14$ & 14 & $8-10$ & 9 & $11-13$ & $14-15$ & 14 \\
\hline Odontostyle length & & $30-34$ & 33,32 & $14-18$ & 17 & $22-25$ & $31-34$ & $32-34$ \\
\hline Odontophore length & & $30-34$ & 34 & $13-17$ & 16 & $22-28$ & $26-32$ & $28-35$ \\
\hline Neck length & & $352-423$ & 437,408 & $194-280$ & 240 & $320-337$ & $338-451$ & $366-507$ \\
\hline Pharyngeal expansion length & & $190-206$ & 221,190 & $71-115$ & 89 & $130-137$ & $174-228$ & $202-247$ \\
\hline Body diameter at neck base & & $36-47$ & $?$ & $22-27$ & 26 & $36-45$ & $41-50$ & $42-52$ \\
\hline midbody & & $36-51$ & $?$ & $22-28$ & 26 & $37-48$ & $44-54$ & $42-57$ \\
\hline anus/cloaca & & $30-37$ & $?$ & $16-20$ & 20 & $25-26$ & $33-38$ & $33-39$ \\
\hline Prerectum length & & $55-98$ & 140,131 & $42-64$ & 82 & $72-108$ & $108-200$ & $130-187$ \\
\hline Rectum length & & $24-31$ & 28,24 & $21-25$ & $?$ & $24-28$ & $23-40$ & $26-33$ \\
\hline Tail length & & $22-32$ & 22,26 & $14-21$ & 16 & $19-22$ & $26-34$ & $25-31$ \\
\hline Spicule length & & - & - & - & 25 & - & - & - \\
\hline Ventromedian supplements & & - & - & - & 5 & - & - & - \\
\hline
\end{tabular}

\section{Results}

Phylum Nematoda Potts, 1932

Class Enoplea Inglis, 1983

Order Dorylaimida Pearse, 1942

Family Nordiidae Jairajpuri \& Siddiqi, 1964

Genus Pungentus Thorne \& Swanger, 1936

Pungentus clavatus Ahmad \& Jairajpuri, 1979

Figs 1A-C, 2

\section{Diagnosis}

This species is distinguished by the length of its body $(1.37-1.91 \mathrm{~mm})$, the lip region being offset by a constriction and 13-15 $\mu \mathrm{m}$ wide, an odontostyle being 30-35 $\mu \mathrm{m}$ long and 2.3-2.5 times lip region width or $1.7-2.1 \%$ of total body length, neck length of 352-437 $\mu \mathrm{m}$, a pharyngeal expansion 190-221 $\mu \mathrm{m}$ long or $50 \%$ of total neck length, a monodelphic-opisthodelphic female genital system, with the anterior genital branch reduced to a very short prevulval sac up to $16 \mu \mathrm{m}$ long or up to 0.4 times the body diameter, a uterus being a simple tube 101-129 $\mu \mathrm{m}$ long or 2.3-2.8 times the body diameter, $V=39-47$, and the female tail being rounded and somewhat clavate $\left(22-31 \mu \mathrm{m}, c=41-75, \mathrm{c}^{\prime}=0.7-1.0\right)$.

\section{Material examined}

Nine females from two locations, in various states of preservation. 


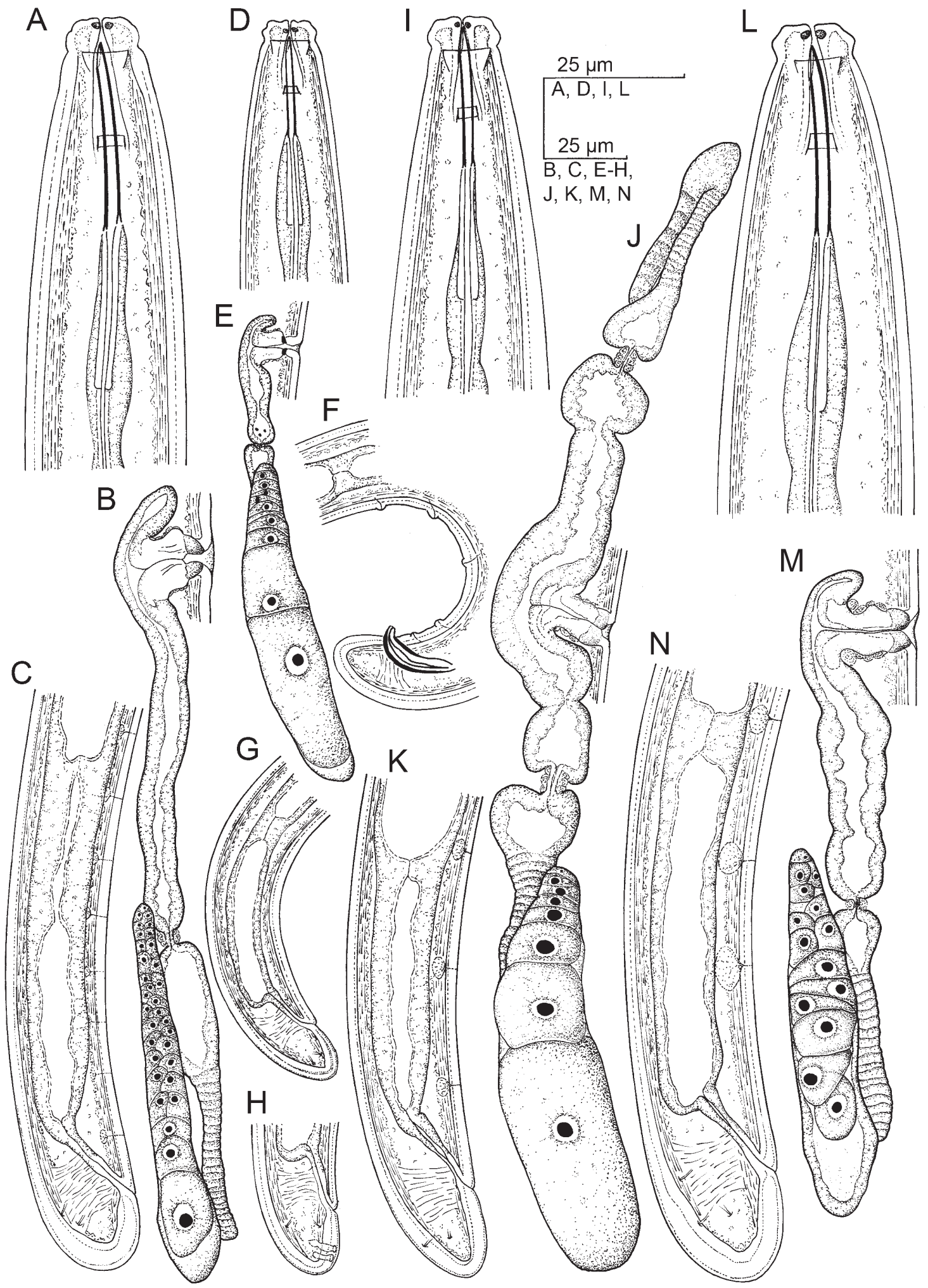

Fig. 1. Iberian Pungentus species. - A-C. Pungentus clavatus Ahmad \& Jairajpuri, 1979. - D-H. Pungentus engadinensis (Altherr, 1950). - I-K. Pungentus marietani Altherr, 1950. - L-N. Pungentus silvestris Coomans \& Geraert, 1962. - A, D, I, L. o, anterior region in lateral median view. B, E, J, M.

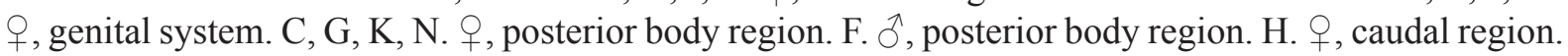




\section{Morphometrics}

See Table 1.

\section{Description}

\section{Female}

Slender to very slender nematodes of medium size, $1.37-1.83 \mathrm{~mm}$ long. Habitus after fixation ventrally curved, especially in posterior body region, G-shaped. Body cylindrical, tapering towards the anterior end. Cuticle two-layered, 2.0-3.0 $\mu \mathrm{m}$ thick in anterior region, 2.0-3.0 $\mu \mathrm{m}$ at mid-body and 4.0-6.0 $\mu \mathrm{m}$ on dorsal side of tail; its outer layer with very fine transverse striation and thinner than inner one. Lateral chord $9-11 \mu \mathrm{m}$ wide or occupying $21-28 \%$ of mid-body diameter, very granular but lacking any differentiation. Ventral body pores perceptible along the entire body. Lip region offset by constriction, 2.2-2.4 times as wide as high and $c a$. one-third (30-34\%) of body diameter at neck base. Lips moderately angular and separate; labial and cephalic papillae distinct, but not especially protruding above cephalic contour. Amphid fovea cup-shaped, opening at level of cephalic constriction, occupying 6.5-8.0 $\mu \mathrm{m}$ or one-half to three-fifths of lip region diameter. Cheilostome almost cylindrical, its walls distinctly thick and sclerotised at the anterior half; perioral refractive dots very conspicuous. Odontostyle 14-18 times as long as wide, 2.3-2.5 times longer than lip region diameter or 1.7-2.1\% of total body length;
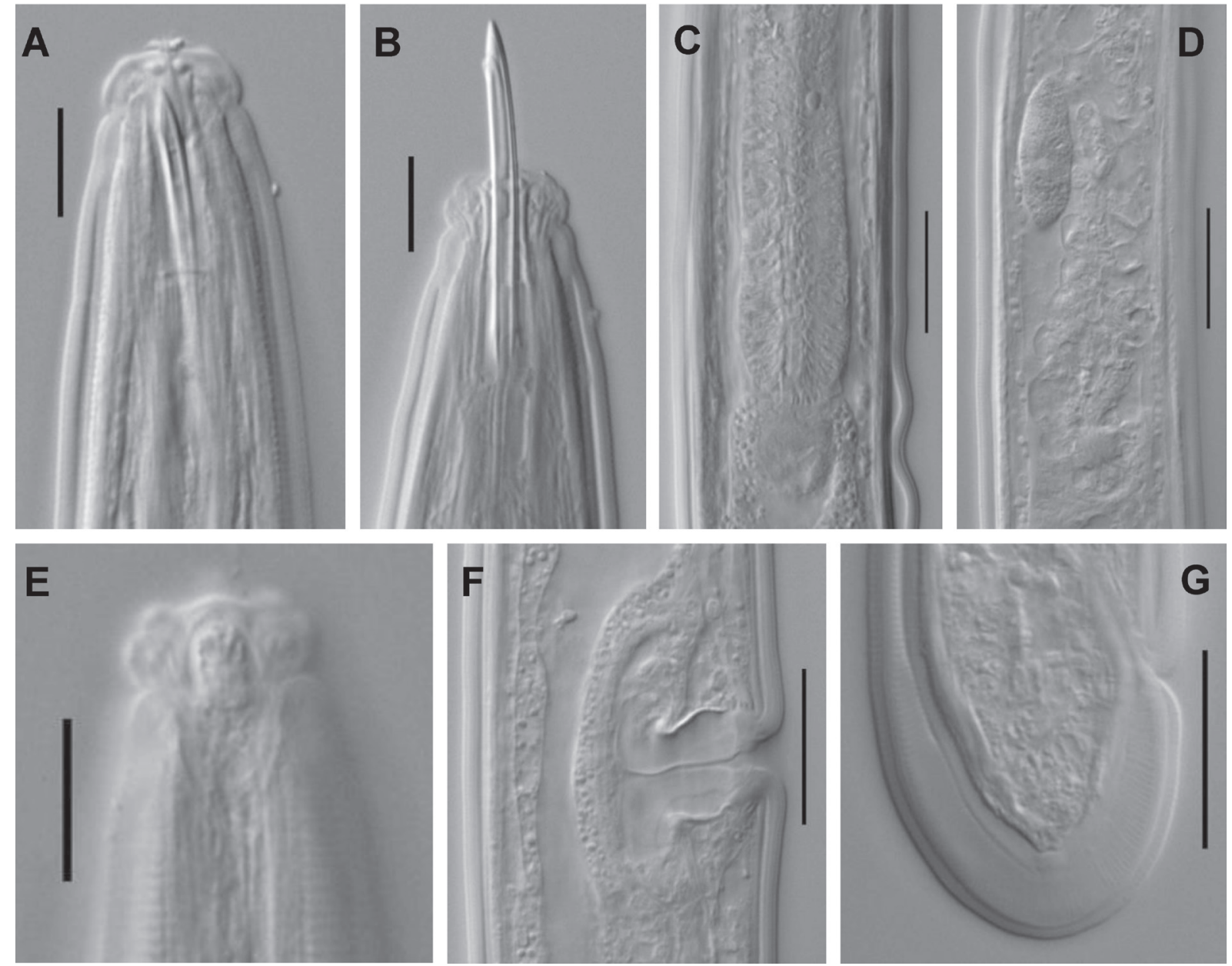

Fig. 2. Pungentus clavatus Ahmad \& Jairajpuri, 1979 ( $\odot$, LM). A-B. Anterior region in lateral median view. C. Pharyngo-intestinal junction. D. Dorsal cell mass at level of uterus. E. Anterior region in lateral surface view. F. Vagina. G. Caudal region. (Scale bars: A, B, E $=20 \mu \mathrm{m} ; \mathrm{C}, \mathrm{D}, \mathrm{F}, \mathrm{G}=10 \mu \mathrm{m}$ ) 
aperture 4.0-5.5 $\mu \mathrm{m}$ long or $12-17 \%$ of its length. Odontophore rod-like, almost equal (0.9-1.1 times) to odontostyle. Guiding ring double, located at 20-22 $\mu \mathrm{m}$ or 1.5-1.6 times the lip region diameter from anterior end. Pharynx enlarging very gradually; basal expansion 9.5-12.1 times as long as wide and 5.35.4 times the corresponding body diameter, occupying one-half (50\%) of total neck length. Pharyngeal gland nuclei located as follows: $\mathrm{DO}=52-53, \mathrm{DN}=54-55, \mathrm{~S}_{1} \mathrm{~N}_{1}=73, \mathrm{~S}_{1} \mathrm{~N}_{2}=74, \mathrm{~S}_{2} \mathrm{~N}=83-88$. Nerve ring at $144-156 \mu \mathrm{m}$ from anterior end or $36-38 \%$ of total neck length. Cardia rounded conoid, $10-11 \mathrm{x}$ 10-11 $\mu \mathrm{m}$. Genital system monodelphic-opisthodelphic; anterior branch reduced to a short to vestigial, uterine, prevulval sac up to $16 \mu \mathrm{m}$ long or up to 0.4 body diameters; posterior branch well developed, 180-305 $\mu \mathrm{m}$ long. Ovary 44-218 $\mu \mathrm{m}$ long, often reaching and surpassing the sphincter level; oocytes first in two or more rows, then in one row. Oviduct 77-124 $\mu \mathrm{m}$ long, or 1.9-2.4 times the body diameter, consisting of a slender portion with prismatic cells and a moderately developed pars dilatata. Sphincter distinct between oviduct and uterus. Uterus a simple tube-like structure, 101-129 $\mu \mathrm{m}$ long or 2.3-2.8 times the body diameter. Sperm cells absent within the genital tract. Uterine eggs $96-108$ x 36-40 $\mu \mathrm{m}$. A distinct dorsal cell mass or coelomocyte (see Fig. 2D) is present at level of oviduct or uterus in two of the specimens examined. Vagina extending inwards 20-25 $\mu \mathrm{m}$ or about one-half (43-54\%) of body diameter; pars proximalis almost as long as wide, 13-18 x 12-16 $\mu \mathrm{m}$, with convergent walls and enveloped by weak circular musculature; pars refringens with two weakly sclerotized pieces; pars distalis 5.5-7.0 $\mu \mathrm{m}$ long. Vulva a pre-equatorial, short transverse slit, which is preceded by a depression of body surface. Prerectum 2.5-2.6 anal body diameters long. Rectum 30-31 $\mu \mathrm{m}$ long, almost equal (0.9-1.0 times) to anal body diameter. Tail short and rounded, more or less clavate. Caudal pores two pairs, one subdorsal, another sublateral, at the middle of tail.

\section{Male \\ Unknown.}

\section{Distribution}

Pungentus clavatus was collected from two localities: the province of Jaén (southern Iberian Peninsula), Cazorla, Segura y Las Villas Natural Park Road to Segura river source (38 $17^{\prime}$ N - $2^{\circ} 39^{\prime}$ W), in association with pine forest; and the province of Huesca (northern Iberian Peninsula), road from Somport to Huesca (42 $34^{\prime} \mathrm{N}-0^{\circ} 32 ' 58^{\prime}$ ' W), associated to Mediterranean brushwood, with dominant species Buxus sempervirens Linnaeus, 1753, Juniperus oxycedrus Linnaeus, 1753, Rosa canina Linnaeus, 1753, and Rubus sp.

\section{Remarks}

Although new data are provided and the ranges of many morphometric features are extended, the present description agrees very well with the original one. In addition to the type locality in India, P. clavatus has been reported from Italy (Vinciguerra \& Giannetto 1987), Poland (Winiszewska-Slipinska 1987a) and Spain (Hernández et al. 1988). Winiszewska-Slipinska (op. cit.) also mentioned its occurrence in Canada. No significant interpopulational variation has been reported in this species. The most relevant and characteristic feature of the species is the clavate shape of its caudal region. Pungentus clavatus might be a widely distributed species in the Holarctic.

\section{Pungentus engadinensis (Altherr, 1950)}

$$
\text { Figs 1D-H, 3-4 }
$$

\section{Diagnosis}

This species is distinguished by its body length of $0.77-1.21 \mathrm{~mm}$, a three-layered cuticle (especially distinct at caudal region), a lip region offset by a constriction and being 8-10 $\mu \mathrm{m}$ wide, an odontostyle 14-20 $\mu \mathrm{m}$ long and 1.7-1.9 times the lip region width or 1.5-2.2\% of the total body length, a neck 194- 
$280 \mu \mathrm{m}$ long, a pharyngeal expansion $71-115 \mu \mathrm{m}$ long or 35-42\% of total neck length, a monodelphicopisthodelphic female genital system, with anterior genital branch absent, uterus a simple tube 39-44 $\mu \mathrm{m}$ long or 1.4-1.8 times the body diameter, $V=41-54$, a rounded tail $\left(14-28 \mu \mathrm{m}, c=40-63, c^{\prime}=0.8-1.1\right)$, spicules $25-28 \mu \mathrm{m}$ long and three to five widely spaced, ventromedian supplements that lack hiatus.
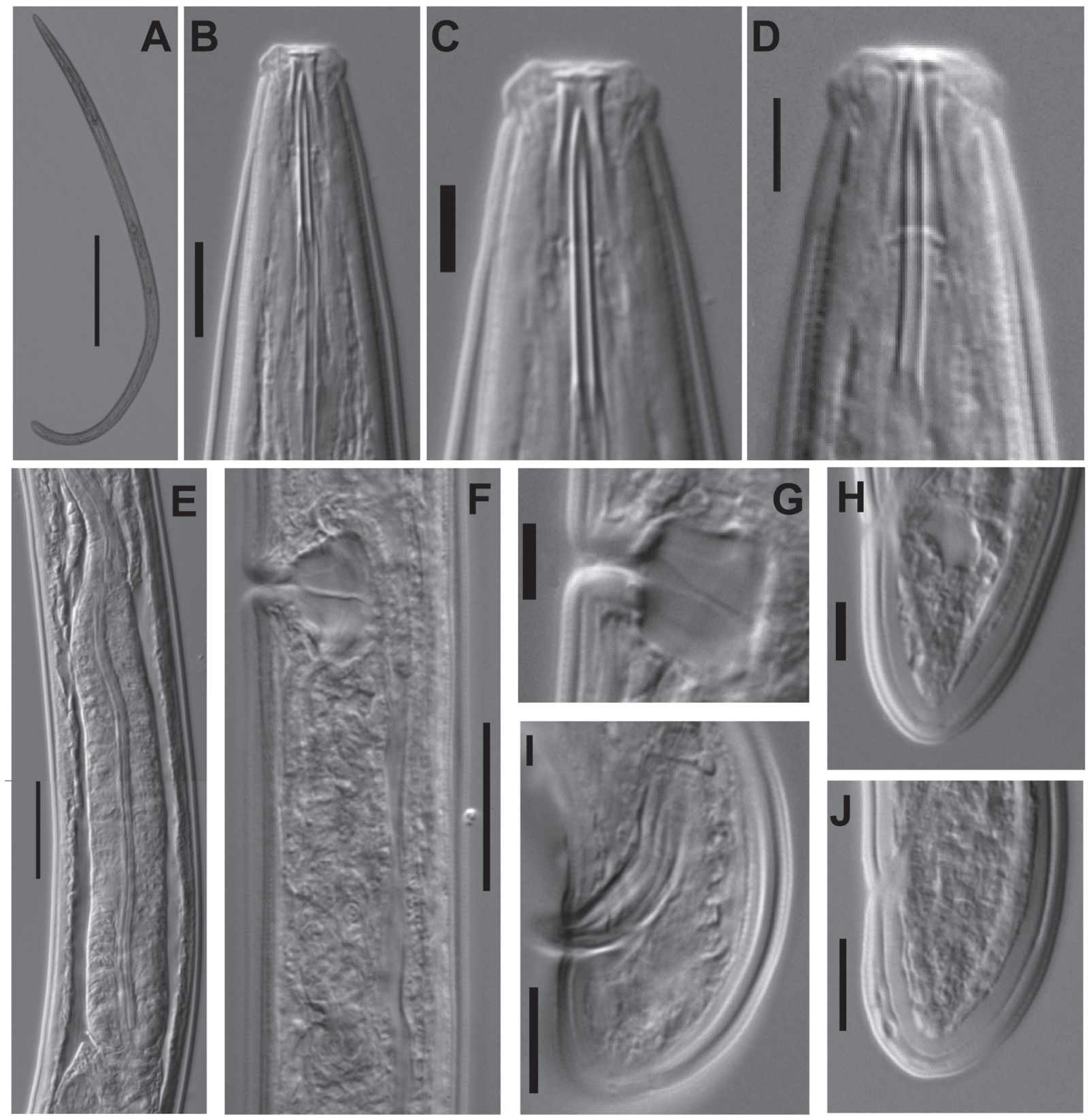

Fig. 3. Pungentus engadinensis (Altherr, 1950) (LM). A. + , entire. B-D. Anterior region in median view. E. Pharyngeal expansion. F. $q$, part of posterior genital branch. G. Vagina. H, J. $q$, caudal region. I. $\rho^{\wedge}$, caudal region and spicules. (Scale bars: $A=200 \mu \mathrm{m} ; \mathrm{B}, \mathrm{J}, \mathrm{K}=10 \mu \mathrm{m} ; \mathrm{C}, \mathrm{D}, \mathrm{G}, \mathrm{I}=5 \mu \mathrm{m} ; \mathrm{E}, \mathrm{F}=20 \mu \mathrm{m}$ ) 


\section{Material examined}

More than one hundred females and one male from more than 20 locations, in various states of conservation.

\section{Morphometrics}

See Table 1.

\section{Description}

\section{General features of adults}

Slender nematodes of small to medium size, $0.77-1.21 \mathrm{~mm}$ long. Habitus after fixation curved ventrad, $\mathrm{C}$-shaped in females, G-shaped in male. Body cylindrical, tapering towards the anterior end. Cuticle three-layered, especially distinguishable at caudal region, $1.5-2.5 \mu \mathrm{m}$ thick in anterior region and at mid-body and 2.5-4.0 $\mu \mathrm{m}$ on dorsal side of tail; outer layer with very fine transverse striation. Lateral chord 5.5-6.5 $\mu \mathrm{m}$ wide or occupying 19-24 \% of mid-body diameter, very granular but lacking any differentiation. Ventral body pores perceptible along the entire body. Lip region offset by constriction, 2.4-3.2 times as wide as high and $c a$. one-third (31-38\%) of body diameter at neck base. Under SEM, lips mostly amalgamated and somewhat angular, lacking any distinguishable striation; labial and cephalic papillae very distinct and visibly protruding, the inner labial papillae situated at the top of low but perceptible lobes; perioral area with (apparently) four small elevations (liplets) surrounding the short dorsoventral, slit-like oral opening. Amphid fovea cup-shaped, opening at level of cephalic constriction, occupying 5.0-5.5 $\mu \mathrm{m}$ or about three-fifths of lip region diameter. Cheilostome almost cylindrical, but a little wider at its posterior half and with its walls distinctly thicker at the anterior half; circum-oral
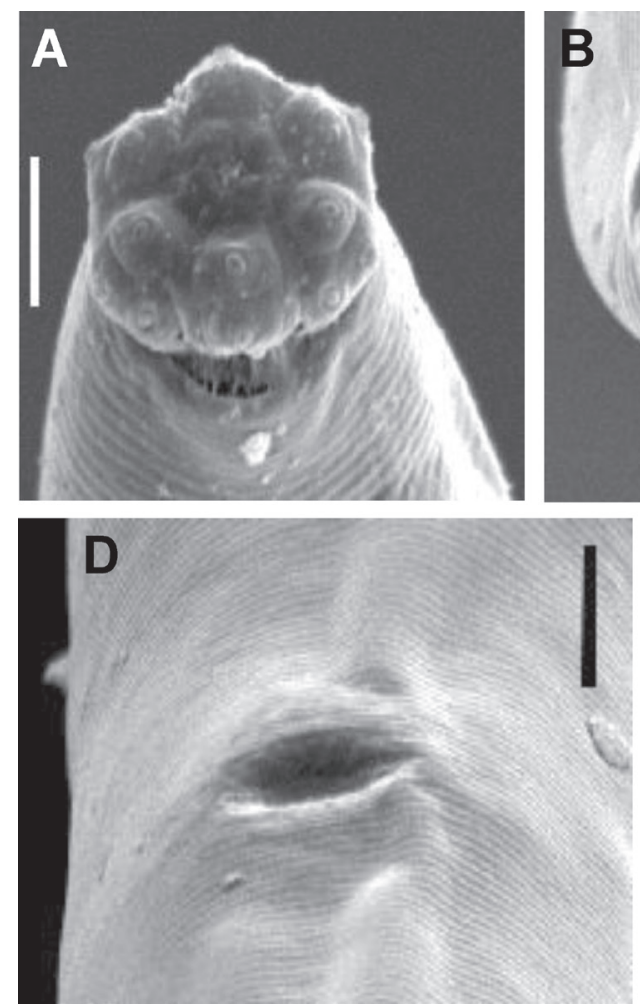
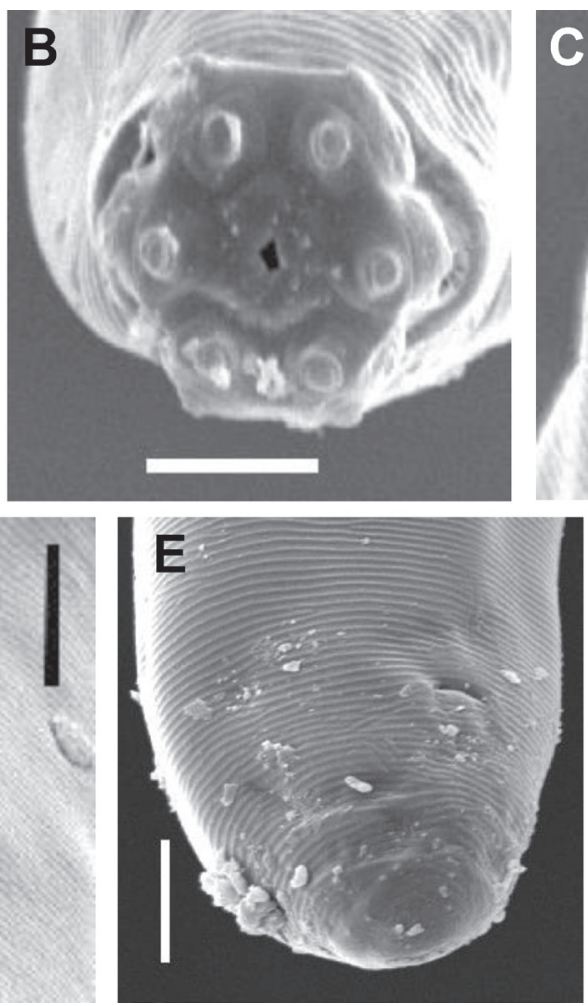
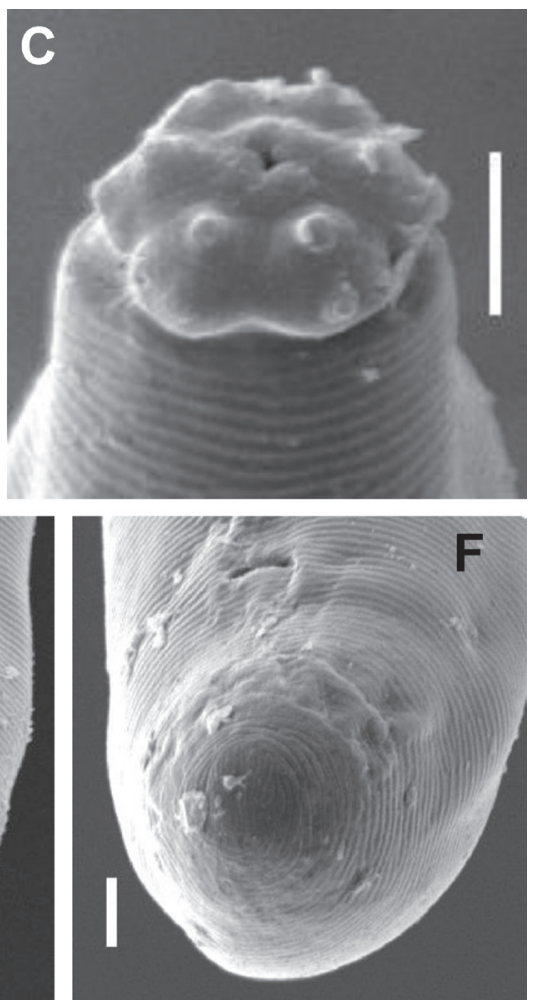

Fig. 4. Pungentus engadinensis (Altherr, 1950) (SEM). A. Lip region in lateral view. B. Same in frontal view. C. Same in ventral view. D. Vulva in ventral view. E-F. Caudal region in ventral view. (Scale bars: $5 \mu \mathrm{m})$ 
refractive dots very conspicuous. Odontostyle 11-14 times as long as wide, 1.8-1.9 times longer than lip region diameter or $1.5-2.2 \%$ of total body length; aperture $2.5-3.0 \mu \mathrm{m}$ long or less than one-sixth its length. Odontophore rod-like, but with small thickenings at its base, nearly as long (0.9-1.1 times) as odontostyle. Guiding ring double, located at 10-11 $\mu \mathrm{m}$ or 1.1-1.3 times the lip region diameter from anterior end. Pharynx enlarging very gradually; basal expansion 5.5-7.4 times as long as wide and 3.13.9 times the corresponding body diameter, occupying about two-fifths (36-41\%) of total neck length. Pharyngeal gland nuclei obscure in the specimens examined. Nerve ring at $80-91 \mu \mathrm{m}$ from anterior end or $32-38 \%$ of total neck length. Cardia rounded conoid, 5.0-6.5 x 7-10 $\mu \mathrm{m}$.

\section{Female}

Genital system monodelphic-opisthodelphic: anterior branch absent and posterior one moderately developed, 76-125 $\mu \mathrm{m}$ long. Ovary 53-110 $\mu \mathrm{m}$ long, often reaching and surpassing the sphincter level; oocytes first in two or more rows, then in one row. Oviduct 39-63 $\mu \mathrm{m}$ long, or 1.5-2.4 times the body diameter, consisting of a slender portion with prismatic cells and a moderately developed pars dilatata. Sphincter distinct between oviduct and uterus. Uterus a simple tube-like structure, 39-44 $\mu \mathrm{m}$ long or 1.41.8 times the body diameter. Uterine egg $82-92 \times 21-26 \mu \mathrm{m}, 2.5-3.5$ times as long as the corresponding body diameter. Vagina extending inwards $12-17 \mu \mathrm{m}$ or one-half to three-fifths $(50-60 \%)$ of body diameter; pars proximalis 7-9 × 6-12 $\mu \mathrm{m}$, with parallel or distally convergent walls and enveloped by weak circular musculature; pars refringens with two small, rectangular or triangular pieces measuring 1 x $3 \mu \mathrm{m}$ and with a combined width of 5-6 $\mu \mathrm{m}$; and pars distalis 3-4 $\mu \mathrm{m}$ long. Vulva a nearly equatorial, about $5 \mu \mathrm{m}$ long, transverse slit. Prerectum 2.3-4.1, rectum 0.8-1.2 anal body diameters long. Tail short and rounded, visibly more convex dorsally; the cuticle at its level consisting of a thick inner layer, a distinct intermediate layer and thinner outer layer, occasionally bearing blister-like structures (saccate bodies). Two pairs of causal pores, one subdorsal, another sublateral, at the middle of the tail.

\section{Male}

Very rare, only one specimen found among several dozens of females. Genital system diorchic, with opposite testes. In addition to the ad-cloacal pair, situated at $6.5 \mu \mathrm{m}$ from cloacal aperture, there is a series of five widely spaced, $10-20 \mu \mathrm{m}$ apart, ventromedian supplements, the most posterior of which is located $9.5 \mu \mathrm{m}$ from the ad-cloacal pair, within the range of spicules. Spicules dorylaimoid, about 5.0 times as long as wide and 1.2 times the body diameter. Lateral guiding pieces obscure. Caudal region similar to that of the female.

\section{Distribution}

Pungentus engadinensis is the most widely spread species of its genus in the southern Iberian Peninsula, having been collected from more than 20 locations with many kinds of natural and cultivated systems, whose dominant plant species are holm-oak (Quercus spp.), Mediterranean brushwood (Cistus spp.), pine (Pinus spp.), poplar (Populus nigra Linnaeus, 1753), almond (Prunus amygdalus Batsch, 1801), Mahaleb cherry (Prunus mahaleb Linnaeus, 1753), hazel (Corylus avellana Linnaeus, 1753), etc.

\section{Remarks}

The above description of Iberian populations perfectly fits the available information about this species, especially the contributions by Andrássy (1962) and Coomans \& Geraert (1962), who provided detailed data and illustrations. Nevertheless, some relevant features such as the three-layered nature of the cuticle, the morphology of the lip region and the structure of the female genital system are here described for the first time. Besides, the range of some measurements (body length, tail length, etc.) and morphometrics (vulva position) are in general extended.

Pungentus engadinensis is certainly the most common species in this genus, having been reported from eleven countries on three continents, all of them in the Holarctic: Belgium (Coomans \& Geraert 1962), 
Canada (Winiszewska-Slipinska 1987a; Andrássy 1991), Hungary (Andrássy 1962, 1991, 2009), Iraq (Vinciguerra 2006), Italy (Zullini 1971, 1975), Poland (Brzeski 1963; Winiszewska-Slipinska 1987a, b), Spain (Castillo et al. 1985), Switzerland (Altherr 1950b, 1952, 1953), the Netherlands (Loof \& Coomans 1970; Bongers 1988), United Kingdom (Wasilewska 1967) and USA (Vinciguerra 2006).

Pungentus marietani Altherr, 1950

Figs 1I-K, 5

P. alpinus Vinciguerra \& Giannetto, 1984: 49, figs 1-3.

\section{Diagnosis}

This species is distinguishable by the length of its body $(1.15-1.66 \mathrm{~mm})$, the lip region being offset by a constriction and 11-15 $\mu \mathrm{m}$ wide, an odontostyle being 22-28 $\mu \mathrm{m}$ long and 1.9-2.3 times lip region width or $1.5-2.1 \%$ of total body length, neck length of $320-337 \mu \mathrm{m}$, a pharyngeal expansion 130-176 $\mu \mathrm{m}$ long or $39-43 \%$ of total neck length, a didelphic-amphidelphic female genital system, a uterus being tripartite and 56-68 $\mu \mathrm{m}$ long or 1.4-1.6 times the body diameter, $V=42-52$, and the female tail being rounded conoid $\left(19-26 \mu \mathrm{m}, c=52-74, c^{\prime}=0.7-1.0\right)$.

\section{Material examined}

Five females from one location, in various states of preservation.

\section{Morphometrics}

See Table 1.

\section{Description}

\section{Female}

Moderately slender to slender nematodes of medium size, 1.15-1.56 mm long. Habitus after fixation ventrally curved, especially in the posterior body region, C- or G-shaped. Body cylindrical, tapering towards the anterior end. Cuticle three-layered, especially perceptible at the tail, 1.5-2.5 $\mu \mathrm{m}$ thick in anterior region, 2.0-2.5 $\mu \mathrm{m}$ at mid-body and 4.0-5.0 $\mu \mathrm{m}$ on dorsal side of tail; outer layer with very fine transverse striation, intermediate layer thicker than the outer and inner layers. Lateral chord 5.5-7.0 $\mu \mathrm{m}$ wide or occupying $12-19 \%$ of mid-body diameter, very granular, but lacking any differentiation. Lateral pores comparatively coarse, in two rows at the margins of lateral chord; ventral pores well perceptible along entire body (Fig. 1K), apparently connecting with sub-epidermal gland bodies. Lip region offset by constriction, 2.4-2.5 times as wide as high and $c a$. one-third (28-35\%) of body diameter at neck base. Lips moderately angular and separate; labial and cephalic papillae distinct, but not especially protruding above cephalic contour. Amphid fovea cup-shaped, opening at level of cephalic constriction, occupying $6.5 \mu \mathrm{m}$ or about one-half (52\%) of lip region diameter. Cheilostome almost cylindrical, its walls distinctly thick and sclerotized at the anterior half; perioral refractive dots or platelets very prominent. Odontostyle 10.0-12.5 times as long as wide, 1.8-2.3 times longer than lip region diameter or $1.5-2.1 \%$ of total body length; aperture $3.0-5.0 \mu \mathrm{m}$ long or $14-19 \%$ of its length. Odontophore rodlike, almost equal (0.9-1.1 times) to odontostyle. Guiding ring double, located at 15-16 $\mu \mathrm{m}$ or 1.2-1.5 times the lip region diameter from anterior end. Pharynx enlarging gradually; basal expansion 5.7-7.1 times as long as wide and 2.9-3.7 times the corresponding body diameter long, occupying about twofifths $(39-43 \%)$ of total neck length. Pharyngeal gland nuclei located as follows: $\mathrm{DO}=52, \mathrm{DN}=56-$ $61, S_{1} N_{1}=77, S_{1} N_{2}=79, S_{2} N=87-90$. Nerve ring at $120-128 \mu \mathrm{m}$ from anterior end or $38 \%$ of total neck length. Cardia rounded conoid, 7-9 x 10-14 $\mu \mathrm{m}$. Genital system didelphic-amphidelphic, with both branches well and equally developed, the anterior 169-182, the posterior 144-210 $\mu \mathrm{m}$ long. Ovaries 43$162 \mu \mathrm{m}$ long; oocytes first in two or more rows, then in one row. Oviduct 82-118 $\mu \mathrm{m}$ long, or 2.2-2.9 
times the body diameter, consisting of a slender portion with prismatic cells and a moderately developed pars dilatata. Oviduct-uterus junction marked by a distinct sphincter. Uterus 56-68 $\mu \mathrm{m}$ long or 1.4-1.6 times the body diameter, apparently tripartite, i.e., consisting of a proximal section with thick walls and distinct lumen, an intermediate narrowing, and a spheroid pars dilatata uteri. Vagina extending inwards $18-22 \mu \mathrm{m}$ or about one-half (44-59\%) of body diameter; pars proximalis almost as long as wide, 13-18 x $12-16 \mu \mathrm{m}$, with convergent walls and enveloped by weak circular musculature; pars refringens not very distinct in the females examined, but two pieces might be present; pars distalis 5.5-7.0 $\mu \mathrm{m}$ long. Vulva a pre-equatorial, short transverse slit, which is preceded by a depression of body surface. Prerectum 2.94.2, rectum 0.9-1.1 anal body diameters long. Tail short and rounded conoid, somewhat more straight ventrally. Caudal pores two pairs, subdorsal, at the anterior half of tail.
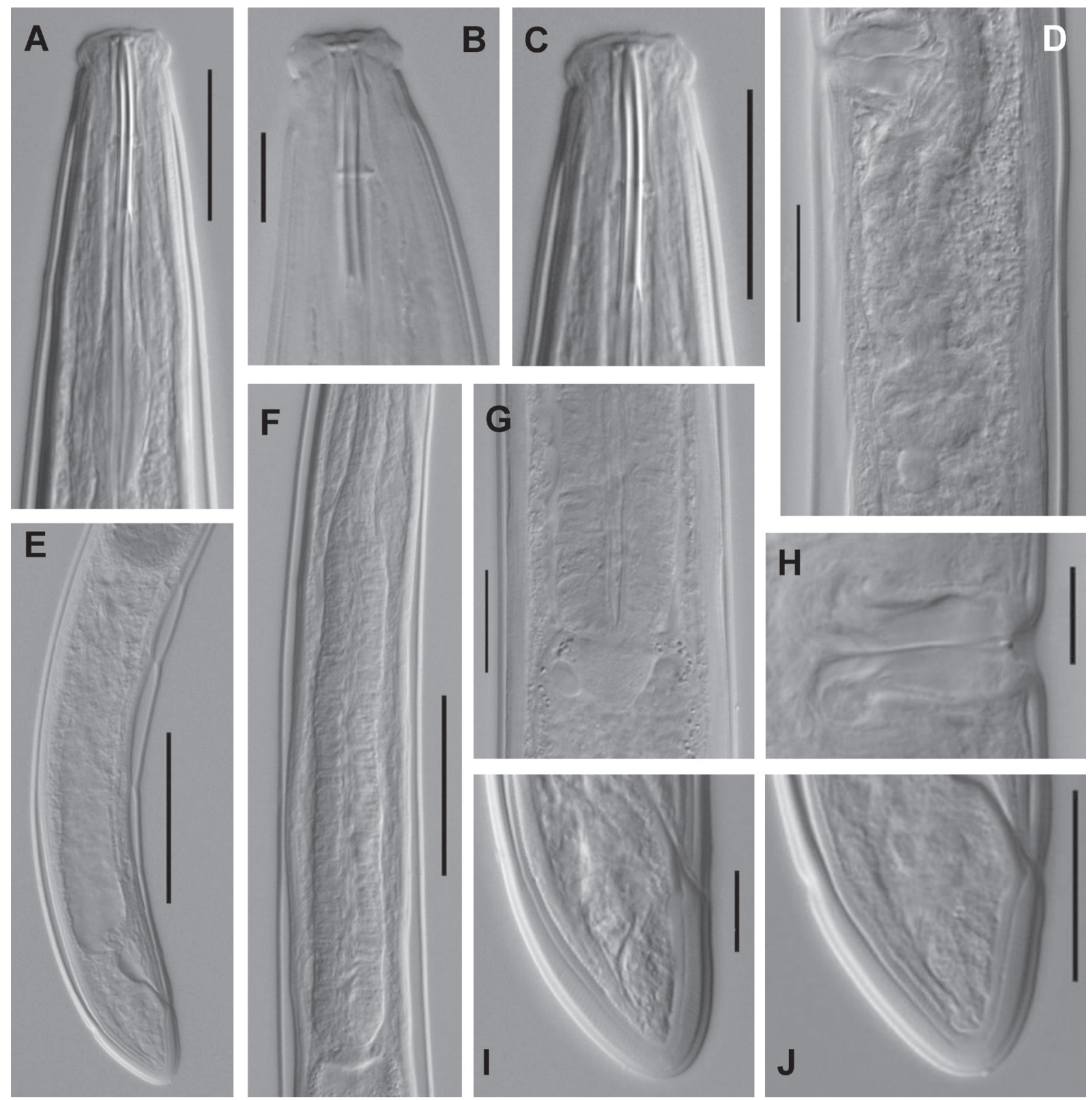

Fig. 5. Pungentus marietani Altherr, 1950 ( $q$, LM). A-C. Anterior region in median view. D. Posterior genital branch. E. Posterior body region. F. Phayngeal expansion. G. Phayngo-intestinal junction. H. Vagina. I-J. Caudal region. (Scale bars: A, C, D, G, J = $20 \mu \mathrm{m} ; \mathrm{B}, \mathrm{H}, \mathrm{I}=10 \mu \mathrm{m} ; \mathrm{E}, \mathrm{F}=50 \mu \mathrm{m}$ ) 


\section{Male \\ Unknown.}

\section{Distribution}

This species was collected from one location in the southern Iberian Peninsula: the province of Granada, Sierra Nevada National Park, near road to Veleta summit $\left(37^{\circ} 7^{\prime} \mathrm{N}-3^{\circ} 32^{\prime} \mathrm{W}\right.$ ), in association with Mediterranean brushwood Retama sphaerocarpa (Linnaeus, 1753) Boissier 1840 as dominant species.

\section{Remarks}

The specimens from the Iberian population of this species are nearly identical to those of the types as described by Altherr (1950a) as well as to the type material of P. alpinus Vinciguerra \& Giannetto, 1984, the latter regarded as a junior synonym by Ahmad et al. (2000). Some morphological features, for instance the nature of the cuticle and the female genital system, are more accurately described here.

Pungentus marietani is certainly another widely distributed species in Europe, where it has been reported from Germany (Ahmad et al. 2000), Italy (Vinciguerra \& Giannetto 1984, as P. alpinus), Poland (Brzeski 1963; Wasilewska 1967; Winiszewska-Slipinska 1987a, b, but see comments below), Switzerland (Altherr 1950a) and the Netherlands (Bongers 1988, as P. alpinus). Besides, Vinciguerra (2006) mentioned its occurrence in Serbia, Slovakia, Macedonia and Canada. The true identity of the specimens studied by Winiszewska-Slipinska (1987a) remains uncertain, because of their larger general size: body $1.5-1.9 \mathrm{~mm}$ long $(\mathrm{n}=27)$ and odontostyle $28-31 \mu \mathrm{m}$; this material probably belongs to another species.

\section{Pungentus silvestris (de Man, 1912)}

Figs 1L-N, 6

P. thornei Goodey, 1943: 6, figs 1-6.

\section{Diagnosis}

This species is characterized by the length of its body $(1.50-2.20 \mathrm{~mm})$, the lip region being offset by a constriction and 12-18 $\mu \mathrm{m}$ wide, an odontostyle being 30-38 $\mu \mathrm{m}$ long and 2.3-2.7 times lip region width or $1.7-1.9 \%$ of total body length, neck length of 366-507 $\mu \mathrm{m}$, a pharyngeal expansion 160-247 $\mu \mathrm{m}$ long or $46-56 \%$ of total neck length, a mono-opisthodelphic female genital system, a uterus being a simple tube 98-124 $\mu \mathrm{m}$ long or 2.1-2.7 times the body diameter, $V=39-46$, and the female tail rounded (26-34 $\left.\mu \mathrm{m}, c=43-90, c^{\prime}=0.7-1.0\right)$.

\section{Material examined}

Twenty females from two locations, in various states of preservation.

\section{Morphometrics}

See Table 1.

\section{Description}

\section{Female}

Slender nematodes of medium size, $1.65-2.10 \mathrm{~mm}$ long. Habitus after fixation ventrally curved, especially in posterior body region, C- or G-shaped. Body cylindrical, tapering towards the anterior end. Cuticle three-layered, 2.0-3.0 $\mu \mathrm{m}$ in anterior region, 2.5-3.0 $\mu \mathrm{m}$ at mid-body and 6.0-8.0 $\mu \mathrm{m}$ on dorsal side of tail; its outer layer with very fine transverse striations and intermediate layer distinctly thicker than inner and outer ones. Lateral chord 10-13 $\mu \mathrm{m}$ wide or occupying one-fifth to one-fourth 
PEÑA-SANTIAGO R., CIOBANU M. \& ABOLAFIA J., Characterization of Iberian Pungentus
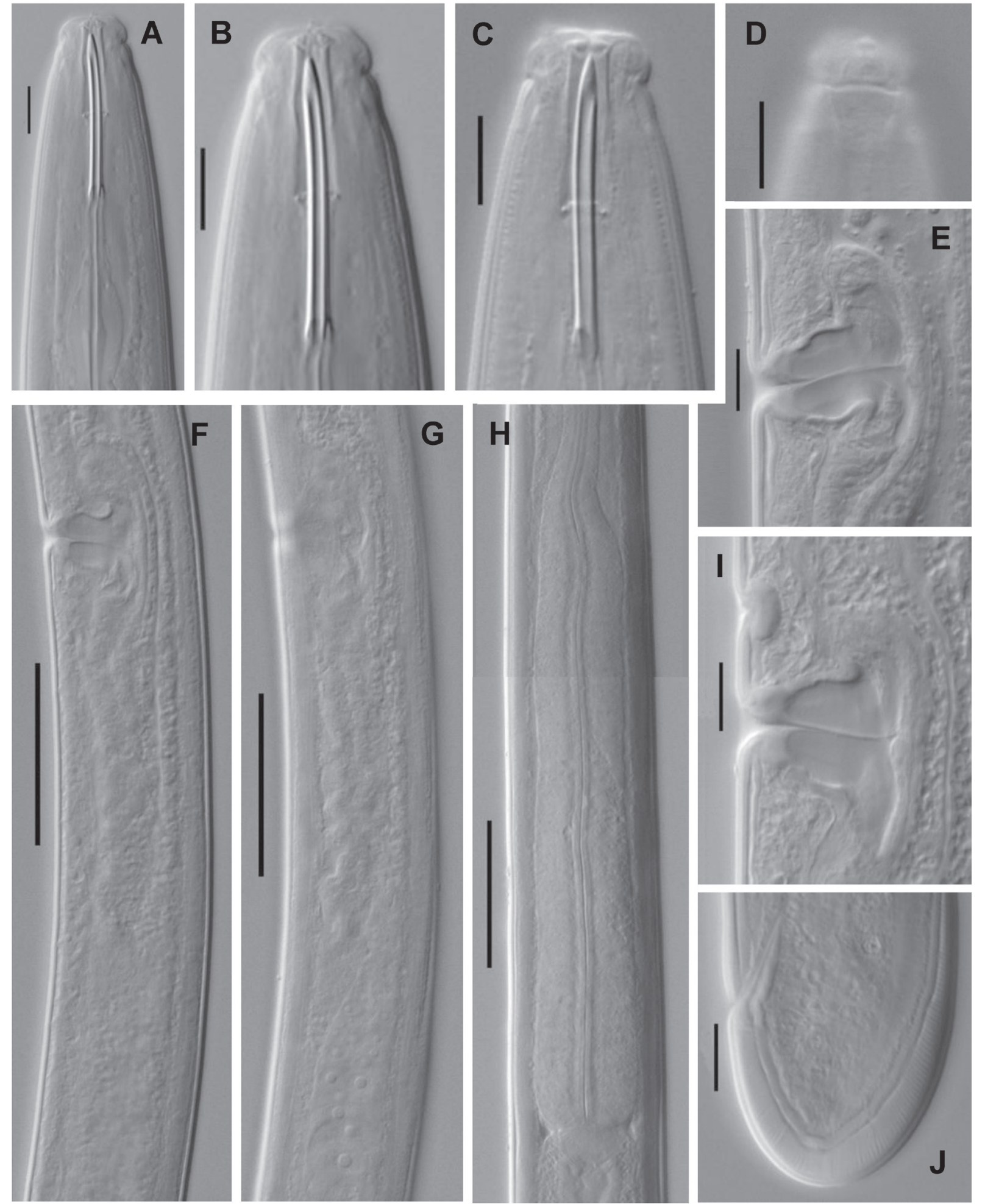

Fig. 6. Pungentus silvestris (de Man, 1912) ( $($, LM). A-C. Anterior region in median lateral view. D. Lip region in surface lateral view. E, I. Vagina and pre-vulval uterine sac. F-G: Posterior genital branch. H. Pharyngeal expansion. J. Caudal region. (Scale bars: A-E, I, J $=10 \mu \mathrm{m} ; \mathrm{F}-\mathrm{H}=50 \mu \mathrm{m}$ ) 
(19-24\%) of mid-body diameter, very granular but lacking any differentiation. Lateral pores obscure in the specimens examined; ventral pores well perceptible (Fig. 1N) along the entire body. Lip region offset by constriction, 2.1-2.6 times as wide as high and $c a$. one-third (29-35\%) of body diameter at neck base. Lips mostly amalgamated and rounded; labial and cephalic papillae distinct, but not especially protruding above cephalic contour. Amphid fovea cup-shaped, opening at level of cephalic constriction, occupying 8-9 $\mu \mathrm{m}$ or about three-fifths (55-62\%) of lip region diameter. Cheilostome almost cylindrical, its walls distinctly thicker and sclerotized at the anterior half; perioral refractive dots or platelets very prominent. Odontostyle 12.2-14.8 times as long as wide, 2.1-2.4 times longer than lip region diameter or $1.7-1.9 \%$ of total body length; aperture $4.0-5.5 \mu \mathrm{m}$ long or $13-18 \%$ of its length. Odontophore rodlike, hardly shorter (0.9 times) than odontostyle. Guiding ring double, located at $21-23 \mu \mathrm{m}$ or 1.6 times the lip region diameter from anterior end. Pharynx enlarging gradually; basal expansion 7.3-9.6 times as long as wide and 4.4-5.6 times the corresponding body diameter long, occupying about one-half (48-56\%) of total neck length. Pharyngeal gland nuclei located as follows: $\mathrm{DO}=48-52, \mathrm{DN}=50-54$, $\mathrm{S}_{1} \mathrm{~N}_{1}=71, \mathrm{~S}_{1} \mathrm{~N}_{2}=$ ?, $\mathrm{S}_{2} \mathrm{~N}=88-89$. Nerve ring at $124-160 \mu \mathrm{m}$ from anterior end or $31-37 \%$ of total neck length. Cardia rounded conoid, 13-18 x 14-17 $\mu \mathrm{m}$. Genital system monodelphic-opisthodelphic. Anterior branch reduced to a very short pre-vulval, uterine sac 8-17 $\mu \mathrm{m}$ long or less than half (0.2-0.4 times) the body diameter. Posterior branch well developed, 176-498 $\mu \mathrm{m}$ long: ovary 98-240 $\mu \mathrm{m}$ long, with oocytes first in two or more rows, then in one row; oviduct 75-122 $\mu \mathrm{m}$ long, or 1.7-2.3 times the body diameter, consisting of a slender portion with prismatic cells and a moderately developed pars dilatata. Sphincter distinct between oviduct and uterus. Uterus apparently a simple tube $98-124 \mu \mathrm{m}$ long or 2.1-2.7 times the body diameter. Vagina extending inwards $23-27 \mu \mathrm{m}$ or about one-half $(50-58 \%)$ of body diameter; pars proximalis almost as long as wide, $14-17 \times 12-14 \mu \mathrm{m}$, with convergent walls and enveloped by weak circular musculature; pars refringens with two weakly sclerotized pieces, 3.5-4.0 x 5 $\mu \mathrm{m}$, and with a combined width of about 9-10 $\mu \mathrm{m}$; pars distalis 3.0-3.5 $\mu \mathrm{m}$ long. Vulva a pre-equatorial, short transverse slit, preceded by a depression of the body surface. A prevulval, gland-like structure ('paravulva') present in one specimen (Fig. 6I). Prerectum 3.1-3.7, rectum 0.8-1.2 anal body diameters long. Tail short and rounded. Caudal pores two pairs, one sublateral, another subdorsal, at the middle of the tail.

\section{Male}

Not found.

\section{Distribution}

This species has been collected from two locations in the southern Iberian Peninsula: the province of Jaén, Cazorla, Segura y Las Villas Natural Park, near the road to the Segura river source $\left(38^{\circ} 17^{\prime}\right.$ $\mathrm{N}-2^{\circ} 39^{\prime} \mathrm{W}$ ), in association with pine forest; and the province of Granada, Sierra Nevada National Park, near the road from Capileira to Veleta $\left(36^{\circ} 57^{\prime} \mathrm{N}-3^{\circ} 21^{\prime} \mathrm{W}\right)$, in a pine forest and among herbaceous plants where the dominant species was Asphodelus albus Miller, 1768.

\section{Remarks}

The present description fits those available from the literature. It agrees especially well with the redescription of the species by Coomans \& Geraert (1962). These authors regarded P. thornei Goodey, 1943 as a junior synonym of $P$. silvestris, an action that seems to be totally justified and herein accepted.

Pungentus silvestris might be a cosmopolitan species. It has been reported from many European countries such as Belgium (Coomans \& Geraert 1962), Bulgaria (Ilieva et al. 1993), Denmark (Yeates 1972, as P. thornei), Germany (Altherr 1968, as P. thornei), Italy (Marinari et al. 1980), Poland (WiniszewskaSlipinska 1987), Russia (Skarbilovich \& Ovsjukova 1989), Spain (Monreal \& Campoy 1982, as $P$. thornei), The Netherlands (de Man 1912; Coomans \& Geraert 1962; Bongers 1988) and United Kingdom (Goodey 1943, as P. thornei). 


\section{Acknowledgements}

The authors especially thank the financial support received from the projects Fauna Ibérica: Nematoda, Dorylaimoidea (excepto Longidoridae) (Spanish Ministry of Science and Innovation, ref. CGL200766786-C08-08; co-financed FEDER) and Revision de la familia Nordiidae (Consejería de Innovación, Ciencia y Empresa, Andalusian Regional Government, Spain; ref. RNM-475). SEM pictures were obtained with the assistance of technical staff and the equipment of 'Servicios Técnicos de Investigación', University of Jaén.

\section{References}

Abolafia J. \& Peña-Santiago R. 2005. Nematodes of the order Rhabditida from Andalucía Oriental, Spain. Pseudacrobeles elongatus (de Man, 1880) comb. n. Nematology 7: 917-926. http://dx.doi. org $/ 10.1163 / 156854105776186415$

Ahmad W., Sturhan D. \& Vinciguerra M.T. 2000. Notes on the identity of Pungentus alpinus Vinciguerra \& Giannetto, 1984 (Dorylaimida: Nordiidae). Journal of Nematode Morphology and Systematics 3: 6368 .

Altherr E. 1950a. De quelques nématodes des garides valaisannes. Extrait du Bulletin de la "Murithienne" 67: 90-103.

Altherr E. 1950b. Les nématodes du Parc National Suisse. Ergebnisse der wissenschaftlichen Untersuchung des schweizerischen Nationalparks 1: 1-46.

Altherr E. 1952. Les nématodes du Parc National Suisse. $2^{\mathrm{e}}$ partie. Ergebnisse der wissenschaftlichen Untersuchung des schweizerischen Nationalparks 3: 315-356.

Altherr E. 1953. Nématodes du sol du Jura vaudois et français (I). Bulletin de la Société Vaudoise des Sciences Naturelles 65: 429-460.

Altherr E. 1968. Nématodes de la nappe phréatique du réseau fluvial de la Saale (Thuringe) et psammiques du Lac Stechlin (Brandebourg du nord). Limnologica (Berlin) 6: 247-320.

Álvarez-Ortega S. \& Peña-Santiago R. 2011. Re-description of two atypical species of Pungentus Thorne \& Swanger, 1936, with proposal of Stenodorylaimus gen. n. (Nematoda, Dorylaimida, Nordiidae). Zootaxa 2799: 49-62.

Andrássy I. 1962. Wiederfund einiger seltener Nematoden-Arten aus der Superfamilia Dorylaimoidea. Nematologische Notizen, 10. Annales Universitatis Scientiarum Budapestinensis, Loránd Eötvös nominatae - Sectio Biologica 5: 3-11.

Andrássy I. 1991. The free-living nematode fauna of the Bátorliget Nature Reserves. The Bátorliget Nature Reserves - after forty years: 129-197.

Andrássy I. 2009. Free-living Nematodes of Hungary. III. Pedozoologica Hungarica ${ }^{0} 5$. Hungarian Natural History Museum, Budapest, Hungary.

Baermann G. 1917. Eine einfache Methode zur Auffindung von Ankylostomum (Nematoden) Larven in Erdproben. Geneeskunding Tijdschrift voor Nederlandsch-Indië 57: 131-137.

Bongers T. 1988. De nematoden van Nederland. Koninklijke Nederlandse Natuurhistorische Vereniging, Utrecht.

Brzeski M. 1963. [Nematoden (Nematoda) des Stadtparks in Skierniewice. I. Erdnematoden]. Fragmenta Faunistica 10: 441-461. (In Polish) 
Castillo P., Peña-Santiago R. \& Jiménez-Millán F. 1985. Modelos de distribución vertical de las especies de nematodos en un biotopo natural. Boletín del Servicio de Defensa contra Plagas e Inspección Fitopatológica 12: 155-162.

Coomans A. \& Geraert E. 1962. Some species of Dorylaimoidea found in Belgium. Nematologica 8: 233-241. http://dx.doi.org/10.1163/187529262X00495

Flegg J.J.M. 1967. Extraction of Xiphinema and Longidorus species from soil by a modification of Cobb's decanting and sieving technique. Annals of Applied Biology 60: 429-437. http://dx.doi. org/10.1111/j.1744-7348.1967.tb04497.x

Goodey T. 1943. Pungentus thornei $\mathrm{n}$. sp., a new dorylaimid nematode from soil. Journal of Helminthology 20: 6-9. http://dx.doi.org/10.1017/S0022149X00034830

Hernández M.A., Mateo M.D. \& Jordana R. 1988. Estudio comparativo entre grupos tróficos de los suelos de cinco bosques de Navarra (tres naturales y dos de repoblación). Actas II Congreso Mundial Vasco de Biología Ambiental II: 323-335.

Ilieva Z.I, Iliev I.L. \& Georgieva S.S. 1993. Description of the male of Pungentus silvestris (de Man, 1912) Coomans et Geraert, 1962 (Nordidae: Nematoda) from Bulgaria. Nematologia Mediterranea 21: 211-214.

Loof P.A.A. \& Coomans A. 1970. On the development and location of the oesophageal gland nuclei in Dorylaimina. Proceedings of the IX International Nematology Symposium (Warsaw, Poland, 1967): $79-161$.

Man J.G. de. 1912. Helminthologische Beiträge. Zoologisches Jahrbuch, Jena 15: 439-464.

Marinari A., Vinciguerra M.T., Vovlas N. \& Zullini A. 1980. Nematodi delle brughiere piemontesi. Quaderni sulla „Struttura delle zoocenosi terrestri“. La brughiera pedemontana. III. C.N.R. AQ/I/116: 101-115.

Monreal J.I. \& Campoy A. 1982. Estudio faunístico del macizo de Quinto Real. VI. Nematodos (Nematoda). Publicaciones de Biología de la Universidad de Navarra, Serie Zoológica 8: 51 pp.

Peña-Santiago R., Abolafia J., Liébanas G., Peralta M. \& Guerrero P. 2003. Dorylaimid Species (Nematoda, Dorylaimida) recorded in the Iberian Peninsula and the Balearic Islands: A Compendium. Monographic papers on Nematology ${ }^{\circ} 1$. Servicio de Publicaciones, Universidad de Jaén.

Siddiqi M.R. 1964. Studies on Discolaimus spp. (Nematoda: Dorylaimidae) from India. Zeitschrift für Zoologische Systematik und Evolutionsforschung 2: 174-184.

Skarbilovich T.S. \& Ovsjukova I.N. 1989. Nematodi rastenii i pochv chukotki. Bulletin Vsesosyolo ordena Trudovogo Krasnogo Znameni instituta gelmintologii im. K. I. Skriabina 50: 122-125.

Thorne G. 1939. A monograph of the nematodes of the superfamily Dorylaimoidea. Capita Zoologica 8: $1-261$.

Thorne G. \& Swanger H.H. 1936. A monograph of the nematode genera Dorylaimus Dujardin, Aporcelaimus n. g., Dorylaimoides n. g. and Pungentus n. g. Capita Zoologica 6: 1-223.

Vinciguerra M.T. 2006. Chapter 15. Dorylaimida Part II: Superfamily Dorylaimoidea. In: Eyualem A., Andrássy I. \& Traunspurger W. (eds) Freshwater Nematodes: Ecology and Taxonomy: 392-467. Ed. CAB International, Wallingford (UK).

Vinciguerra M.T. \& Giannetto L. 1984. Two new species of Pungentus (Dorylaimida, Nematoda) from pasture soils of Alps. Animalia 11: 49-54.

Vinciguerra M.T. \& Giannetto L. 1987. Nematodi delle faggete italiane. Animalia 14: 5-33. 
Wasilewska L. 1967. Analysis of the occurrence of nematodes in alfalfa crops. I. Species composition of nematodes in two alfalfa crops of different age and penetration of species from soil to plants. Ekologica Polska - Seria A 15: 347-371.

Winiszewska-Slipinska G. 1987a. [Species of the genus Pungentus Thorne et Swanger (Nematoda: Dorylaimida) occurring in Poland.] Fragmenta Faunistica 30: 321-330. (In Polish)

Winiszewska-Slipinska G. 1987b. [The free-living soil nematodes (Nematoda) of the Swietokrzyskie Mountains.] Fragmenta Faunistica 31: 11-41. (In Polish)

Yeates G.W. 1972. Nematoda of a Danish beech forest. Oikos 23: 178-189.

Zullini A. 1971. Studio sulle variazioni del popolamento nematologico in un muschio. Estratto dai Rendiconti, Classe di Scienze (B) 105: 89-106.

Zullini A. 1975. Nematodi ripicoli del Po. Estratto dai Rendiconti, Classe di Scienze (B) 109: 130-142.

Manuscript received: 5 April 2013

Manuscript accepted: 1 July 2013

Published on: 5 August 2013

Topic editor: Rudy Jocqué

Desk editor: Kristiaan Hoedemakers

Printed versions of all papers are also deposited in the libraries of the institutes that are members of the EJT consortium: Muséum National d'Histoire Naturelle, Paris, France; National Botanic Garden of Belgium, Meise, Belgium; Royal Museum for Central Africa, Tervuren, Belgium; Natural History Museum, London, United Kingdom; Royal Belgian Institute of Natural Sciences, Brussels, Belgium; Natural History Museum of Denmark, Copenhagen, Denmark. 